\title{
RAGAM BAHASA SANTAI DALAM TUTURAN ILOKUSIONER PADA KEGIATAN DISKUSI PUBLIK SINAU KEDAULATAN DAN KEBUDAYAAN BERSAMA CAK NUN
}

\author{
Talitha Lulu Kharisma ${ }^{1}$ Gigit Mujianto ${ }^{2}$ \\ ${ }^{1,2}$ Universitas Muhammadiyah Malang, Indonesia \\ lithakharisma11@gmail.com ${ }^{1}$, gigit@umm.ac.id ${ }^{2}$
}

\begin{abstract}
The study was intended to analyze the casual language variations in the iloquestionnaire's speechs on the public discussion activities. This study uses sociolinguistics concepts from John $\mathrm{R}$ Searle's theory to analyze the problems of casual language variations and any form of iloquestionnaire's speechs. This study is a qualitative descriptive research. The data collection technique that used is purposive sampling method, which in taking samples is concerned with the purpose and problems of research. Data obtained by using transcription videos of "diskusi publik kedaulatan dan kebudayaan bersama cak Nun". This study uses data analysis techniques in the form of content analysis. The data analysis techniques are as follows: 1) looking back over the data already collected, 2) classifying the data according to the question of variations in casual language and iloquestionnaire's speech, 3) interpreting the data with a sociolinguistic approach and John R Searle's theory, and 4) concluding the findings. Studies showed that discussion activities use a variety of casual language with characteristic Javanese, Alegro forms, elliptic sentences, and a mixture of the foreign language code, English and Arabic, and Normative. In the discussion activities, there are various forms of iloquconsequence, referral, commission, expressive, and declarative.
\end{abstract}

Keywords: casual language, iloquestionnaire's speech, and discussion

\begin{abstract}
ABSTRAK
Penelitian ini bertujuan untuk menganalisis variasi bahasa santai dalam tuturan ilokusioner pada kegiatan diskusi publik. Dalam penelitian ini digunakan konsep sosiolinguistik dengan teori John.R.Searlee untuk menganalisis permasalahan variasi bahasa santai dan macam-macam bentuk tuturan ilokusioner. Penelitian ini termasuk dalam jenis penelitian kualitatif dengan bentuk deskriptif. Metode pengumpulan data menggunakan metode purposive sampling, yang mana dalam mengambil sampel memperhatikan memperhatikan tujuan dan permasalahan dalam penelitian. Data yang diperoleh dengan cara transkripsi video diskusi publik kedaulatan dan kebudayaan bersama cak Nun. Penelitian ini menggunakan teknik analisis data berupa analisis konten. Adapun teknik analisis data tersebut adalah sebagai berikut. 1) Mencermati kembali data yang telah dikumpulkan, 2) Mengelompokkan data sesuai persoalan mengenai variasi bahasa santai dan tuturan ilokusioner, 3) menginterpretasikan data dengan pendekatan sosiolinguistik dan teori John R Searlee, dan 4) menyimpulkan hasil temuan. Hasil penelitian menunjukkan bahwa pada kegiatan diskusi menggunakan variasi bahasa santai dengan karakteristik mengandung unsur bahasa Jawa, bentuk alegro, kalimat elips, mengandung campur kode bahasa asing yaitu bahasa Inggris dan bahasa Arab, dan bahasa tidak normatif. Pada kegiatan diskusi terdapat macam-macam bentuk ilokusioner yaitu tuturan asertif, direktif, komisif, ekspresif, dan deklaratif.
\end{abstract}

Kata kunci: bahasa santai, tuturan ilokusioner, dan diskusi

\section{PENDAHULUAN}

Komunikasi menjadi salah satu alat yang digunakan untuk dapat berinteraksi dengan sesama manusia, maka dari itu bahasa menjadi salah satu komponen penting karena dengan bahasa, komunikasi 
tersebut dapat terjalin. Dalam proses komunikasi menjadi suatu media menyampaikan pesan atau gagasan dari pemikiran manusia lain. Bahasa berbentuk satuan bunyi, tanda, kata, dan kalimat, yang mana penuturannya dapat secara verbal maupun nonverbal. Adapun secara verbal yaitu bahasa dapat diartikulasikan secara langsung sehingga menghasilkan bunyibunyi yang dapat diterima pendengar atau mitra tutur, sedangkan nonverbal yaitu bahasa yang dapat berupa tulisan ataupun bahasa isyarat.

Manusia seiring dengan tumbuh kembangnya mempelajari bahasa sebagai alat komunikasi. Setiap manusia memiliki bahasa ibu atau bahasa pertama yang dipelajari sebagai alat komunikasi dengan manusia lain. Adapun bahasa ini dapat berbeda-beda antara manusia yang satu dengan lainnya karena perbedaan lingkup wilayah atau negara. Misalnya di Indonesia sebagai negara Bhineka Tunggal Ika yang mana salah satunya memiliki keberagaman bahasa, membuat sebagian besar warga negaranya memiliki bahasa Ibu yang berupa bahasa daerah. Kepala Badan Pengembangan dan Pembinaan Bahasa (Badan Bahasa), Dadang Sunandar menyatakan jangan sampai ciri kebhinekaan rusak karena permasalahan bahasa daerah dan bahasa Ibu merupakan faktor utama dan penting dalam (Kemendikbud Turut Peringati Hari Bahasa Ibu Internasional, 2020)). Dengan demikian bahasa Indonesia menjadi bahasa kedua. Oleh karena itu, sebagai warga negara Indonesia harus tetap bisa melestarikan bahasa daerah dan mengutamakan bahasa Indonesia.

Kebudayaan di suatu daerah memberikan sumbangsih dalam terbentuknya suatu bahasa daerah. Bahasa daerah ini terbentuk sebagai Bahasa yang relatif digunakan oleh sebagian yang memiliki kesamaan wilayah ataupun ras suku budaya masyarakat untuk berkomunikasi. Berdasarkan Peraturan Menteri Dalam Negeri Nomor 40 Tahun 2007, menyatakan bahasa daerah adalah suatu bahasa yang digunakan oleh suatu anggota masayarakat mulai dari suku atau kelompok etnis daerah tertentu untuk berkomunikasi dan berinteraksi satu sama lainnya (Kontribusi Kosakata Bahasa Daerah dalam Bahasa Indonesia, Kementerian Pendidikan dan Kebudayaan, t.t.). Bahasa juga tidak terlepas dari kehidupan sosiologis masyarakat dalam suatu daerah.

Kehidupan sosial masyarakat dapat memberikan pengaruh dalam penggunaan bahasa dalam suatu wilayah tertentu. Bahasa dan kehidupan sosial tersebut dikaji secara teoritis dalam ilmu sosiolinguistik. Sosiolinguistik adalah interdisipliner antara bidang ilmu linguistik dan sosiologi yang sangat berkaitan erat (Chaer \& Agustina, 2014:2). Keterkaitan erat dua ilmu tersebut dapat diketahui melalui perbedaan bahasa yang digunakan dalam wilayah tertentu dengan wilayah lain atau perbedaan bahasa yang digunakan dalam situasi-situasi atau kegiatan kemasayarakatan tertentu.

Masyarakat yang bersifat heterogen baik dari tingkat sosial, ekonomi, ras, beserta kebudayan yang berbeda-beda antar satu wilayah dengan wilayah lain menyebabkan adanya variasi bahasa. Poedjosoedarmo menyatakan bahwa variasi berbahasa adalah ragam dalam suatu bahasa yang mana ragam bahasa tersebut memiliki pola yang hampir menyerupai bahasa asalnya (Hayati, 2021:51). Chaer \& Agustina (2014:61) menjelaskan penyebab terjadinya keragaman atau kevariasian bahasa tidak hanya masyarakat yang tidak homogen tetapi juga adanya interaksi sosial yang berbeda dan beragam dalam keadaan tertentu. Variasi bahasa terbagi menjadi empat segi yaitu segi penutur, pemakaian, keformalan, dan sarana (Chaer \& Agustina, 2014:62). Variasi dari segi penutur yang memperhatikan siapa penutur berdasarkan waktu, daerah, dan kedudukan sosial. Variasi dari segi pemakaian yang fokus pada bidang keperluan atau kegiatan apa. Variasi segi keformalan yang memperhatikan pemakaian bahasa berdasarkan situasi kegiatan yang ada. Variasi segi sarana yaitu variasi yang berdasarkan media yang digunakan dalam berbahasa.

Variasi bahasa dari segi keformalan, Martin Joos mengelompokkan variasi bahasa atas lima macam gaya (Inggris: Style), yaitu gaya atau ragam beku (Frogen), gaya atau ragam resmi (formal), gaya atau 
ragam usaha (konsultatif), gaya atau ragam santai (casual), dan gaya atau ragam akrab (intimate) (Chaer dan Agustina, 2014:62). Variasi bahasa santai digunakan pada situasi tidak resmi, misalnya perbincangan dengan keluarga atau teman akrab, berekreasi, berolahraga, dan sebagainya. Pemakaian bahasa santai yang dalam situasi tidak formal ini mengandung unsur leksikal daerah, bentuk alegro, dan bentuk kalimat yang yang tidak normatif.

Selain variasi bahasa terdapat model fungsional bahasa, model adalah replika atau rekayasa dari realitas yang bertujuan menyerdehanakan dan memberikan sistematika dalam memandang dan memahami sistem atau realita Ibrahim (2009:7). Dalam menganalisa permasalahan bahasa tidak hanya melalui variasi bahasa saja tetapi juga dapat melalui model fungsional. Adapun salah satu model fungsional bahasa adalah interaksional. Gumperz dan Goffman melahirkan kajian yang sama sebagai kunci analisis dalam ancangan sosiolinguistik interaksional, yaitu: interaksi antarindividu secara pribadi dan orang lain, serta peran konteks dalam tuturan (Ramadhanti, 2018:292).

Selanjutnya, Searle mengemukakan bahwa tindak tutur adalah produk atau hasil dari suatu kalimat dalam kondisi tertentu dan merupakan kesatuan terkecil dari kombinasi linguistik yang dapat berwujud pernyataan, pertanyaan perintah atau yang lainnya (Andini, 2017:14). Dalam proses tindak tutur memperlihatkan kemampuan berbahasa seseorang melalui pemilihan kata hingga kalimat yang diucapkan. Austin menjelaskan tindak tutur terbagi menjadi 3 peristiwa yaitu lokusi, ilokusi, dan perlokusi. Pada saat seseorang melakukan tuturan baik berupa kata maupun kalimat, maka dalam satu kali tuturan tersebut dapat memuat satu atau dua atau bahkan tiga peristiwa dalam tindak tutur sekaligus. John R. Searle mengklasifikasikan tindak tutur dalam aktivitas bertutur ke dalam lima macam bentuk tuturan yang masing-masing memiliki fungsi komunikatif yaitu Asertif (Assertives), Direktif (Directives), Komisif (Commissives), Ekspresif (Expressives), dan Deklaratif (Declaration) (Rahma, 2018). Dalam bentuk alegro terdapat proses penyingkatan yang tidak beraturan pada beberapa morfem seperti gak (enggak atau tidak), trusn (terusan yang berarti kemudian), trus (terus), km (kamu) (Maya Dwi Jayanti dkk., 2014).

Dalam tuturan asertif terdapat beberapa ciri yang dapat menjadi indikator suatu tuturan termasuk dalam tuturan asertif. Menurut Kreidler tindak tutur asertif dibagi menjadi dua, yaitu tindak tutur asertif langsung dan tak langsung. Tindak tutur asertif langsung diawali dengan kata saya atau kami dan diikuti dengan verba asertif, sedangkan tindak tutur asertif tak langsung juga diikuti dengan verba asertif yang merupakan tuturan yang dituturkan kembali oleh penutur (Yayuk, 2014). Tuturan asertif menyarankan suatu informasi tersebut menggunakan kalimat berdiatesis aktif, seperti dalam menggunakan kata "kita" (Prasasti \& Mujianto, 2020).

Terdapat beberapa indikator yang dapat menunjukkan suatu tuturan termasuk dalam tuturan direktif. Tindak ilokusi direktif memiliki kinerja verbal memerintah yang paling eksplisit jika dibandingkan dengan tindak ilokusi lain. Holmes menyatakan keeksplisitan tindak ilokusi direktif bisa dilihat dari hubungan langsung antara daya ilokusi dengan struktur kalimatnya (Mudiono, 2014). Kata "janganlah" menjadi salah satu ciri tindak direktif yaitu wujud kalimat imperatif yang menggunakan verba performatif berupa verba dasar+lah (Koyimah, 2018). Imperatif merupakan sebuah kalimat yang bertujuan memerintah kepada mitra tutur (Utama dkk,2021:18). Tuturan direktif ditandai dengan adanya penanda tutur modalitas verba + kan pada kata selamatkan (Suryatin, 2018).

Tindak tutur komisif dibagi menjadi dua jenis, yaitu promises dan offers. Promises adalah dalam mengucapkan suatu janji, penutur menjanjikan mitra tutur untuk melakukan seperti yang diucapkannya. Offers, dalam mengucapkan tawaran, penutur menawarkan sesuatu kepada mitra tutur. (Ibrahim, 1993:36). Kata interjeksi yang menjadi salah satu penanda tuturan ekspresif. Interjeksi atau kata seru yang diungkapkan biasanya merupakan perasaan hati penutur. Pemahaman interjeksi menurut 
Kridalaksana adalah kategori yang bertugas mengungkapkan perasaan pembicara dan secara sintakkis tidak berhubungan dengan kata-kata lain dalam ujaran. Menurut Kridalaksana (2007:121) interjeksi dapat ditemui dalam:

1) Bentuk dasar yaitu aduh, aduhai, ah, ahoi, ai, amboi, asyoi, ayo, bah, cih, cis, eh, hai, idih, ih, lho, mari, oh, nah, sip, wah, wahai, yaaa.

2) Bentuk turunan, berasal dari kata-kata biasa atau penggalan kalimat arab. Contoh: alhamdulillah, astaga, brengsek, buset, dubilah, duilah, insyaAllah, masyaAllah, syukur, halo, innalillahi, yahud.

Leech telah mengemukakan pendapatnya mengenai ciri atau kekhasan yang terdapat pada tuturan deklaratif, diantaranya adalah (Titasari, 2017) (a) tuturan deklaratif memiliki sifat performatif, tuturan performatif tidak dievaluasi sebagai benar atau salah, tetapi sebagai tepat atau tidak tepat. (b) setiap tuturan deklaratif disertai tindakan fisik. (c) setiap ujaran deklaratif selalu memiliki makna penting sesuai dengan konteks yang mendasari. Makna yang terdapat pada tindak tutur deklaratif didasarkan pada konteks terjadinya tuturan tersebut.

Peristiwa tindak tutur dapat terjadi dimana saja dan kapan saja, bahkan dalam kegiatan berkomunikasi sehari-hari yang bersifat tidak formal hingga formal. Kegiatan diskusi merupakan salah kegiatan yang hampir seluruh manusia melakukannya, baik untuk kepentingan pribadi maupun kelompok. Diskusi merupakan suatu bentuk tukar pikiran yang teratur dan terarah,baik dalam kelompok kecil maupun dalam kelompok besar dengan tujuan untuk mendapatkan suatu pengertian dan keputusan bersama mengenai sebuah masalah (Nurulita dkk., 2019:3). Pada saat berlangsungnya diskusi dalam ranah formal atau tidak formal dapat menjadi objek penelitian bahasa yang mengkaji tentang variasi bahasa dan model fungsional kebahasaannya.

Beberapa penelitian terdahulu yang memiliki fokus kajian tuturan ilokusioner yaitu pertama, dilakukan oleh A'yuni \& Parji, (2017) yang berjudul Tindak Tutur
Ilokusi Novel Surga Yang Tidak Dirindukan Karya Asma Nadia (Kajian Pragmatik). Dalam penelitian tersebut diperoleh hasil penelitian bentuk tidak tutur ilokusi dalam novel Nadia terdapat 5 fungsi yaitu ekspresif yang meliputi meminta maaf, memuji, dan menyalahkan; asertif yang meliputi meminta maaf, memuji, dan menyalahkan; direktif yang meliputi memerintah, menyuruh, menganjurkan, meminta, memohon, dan menasehati; dan komisif yang meliputi menolak dan berjanji. Kedua, penelitian yang dilakukan oleh Stambo \& Ramadhan (2019) dengan judul Tindak Tutur Ilokusi Pendakwah Dalam Program Damai Indonesiaku Di TV ONE. Diperoleh hasil penelitian dalam program damai Indonesiaku di TV ONE, terdapat 5 bentuk tindak tutur ilokusi yaitu asertif, direktif, komisif, ekspresif, dan deklarasi.

Penelitian terdahulu yang memiliki fokus kajian keformalan bahasa yaitu ketiga, penelitian yang dilakukan oleh Sudaryati (2019) dengan judul Variasi Keformalan Dalam Wacana Kelas Mahasiswa Angkatan 2016 Kelas A Program Studi Pendidikan Bahasa Indonesia Universitas Tadulako. Diperoleh hasil penelitian di dalam wacana kelas juga terdapat variasi keformalan yang terdiri dari ragam resmi, ragam usaha, ragam santai, dan ragam akrab. Berbeda dengan beberapa penelitian terdahulu, penelitian ini memiliki objek penelitian dan fokus kajian yang berbeda. Fokus kajian penelitian ini mengenai variasi bahasa santai dan macammacam bentuk tuturan ilokusioner. Dalam mengkaji variasi bahasa santai peneliti menggunakan pendekatan Sosiolinguistik sedangkan dalam tuturan ilokusioner menggunakan teori John R. Searle.

\section{METODE PENELITIAN}

Metode penelitian dalam penelitian ini menggunakan metode deskriptif, yaitu penelitian yang memaparkan analisis data dengan menggunakan deskripsi. Pendekatan yang digunakan dalam penelitian ini adalah Sosiolinguistik, sosiolinguistik adalah salah satu cabang ilmu linguistik yang bersifat interdisipliner antara ilmu linguistik dengan ilmu sosiologi yang memiliki fokus kajian mengenai hubungan antara bahasa dengan 
berbagai faktor dalam masyarakat tutur (Chaer dan Agustina, 2014:4). Penelitian juga menggunakan teori $\mathrm{J}$ teori John $\mathrm{R}$. Searle mengenai tuturan ilokusioner.

Sumber data dalam penelitian ini adalah kanal YouTube "UB TV" pada video yang berjudul Diskusi Publik Sinau Kedaulatan Pendidikan \& Kebudayaan Cak Nun Part 3 dan Part 4. Video tersebut dipublikasikan pada Oktober 2015 yang secara keseluruhan berdurasi 52 menit. Metode pengumpulan data menggunakan metode purposive sampling, metode yang mana dalam mengambil sampel memperhatikan memperhatikan tujuan dan permasalahan dalam penelitian. Data yang diperoleh dengan cara melalui proses transkripsi dua video youtube. data pada penelitian ini berupa kata atau kalimat yang berkaitan dengan variasi bahasa santai dan tuturan ilokusioner. Adapun teknik analisis data tersebut adalah sebagai berikut. 1) Mencermati kembali data yang telah dikumpulkan, 2) Mengelompokkan data sesuai persoalan mengenai variasi bahasa santai dan tuturan ilokusioner, 3) menginterpretasikan data dengan pendekatan sosiolinguistik dan teori John R.Searle, dan 4) menyimpulkan hasil temuan.

\section{HASIL DAN PEMBAHASAN}

Berdasarkan analisis data terhadap fokus kajian variasi bahasa santai dalam tuturan ilokusioner pada video kegiatan diskusi publik bersama Cak Nun diperoleh hasil penelitian yang terbagi menjadi dua yaitu variasi bahasa santai dan jenis-jenis tindak tutur ilokusioner.

\section{Variasi Bahasa Santai}

Pada kegiatan diskusi publik bersama cak Nun telah ditemukan beberapa tuturan yang mengandung ciri-ciri linguistik variasi bahasa santai sebagai berikut:

Dalam konteks kegiatan diskusi yang memberikan kesempatan beberaa peserta untuk memberikan pertanyaan kepada pemateri.

Data 1 pada menit 1:50

Peserta : saya dari fakultas Psikologi, jadi saya tanya Cak Nun karna sudah.. tadi sudah banyak yang tanya, sakjane eee.... tugas pendidikan dan penyebaran pendidikan itu tugasnya siapa sih? Itu aja, Makasih

Dalam data 1 termasuk variasi bahasa santai karena dalam kalimat yang digunakan mengandung unsur leksikal daerah bahasa Jawa Timur yaitu pada kata sakjane yang dalam bahasa Indonesia memiliki arti seharusnya. Penggunaan unsur bahasa Jawa Timur tersebut menjadi indikator dalam menentukan variasi bahasa santai. Hal ini pendapat Malabar (2015) ragam santai ditandai dengan adanya pemakaian bahasa yang sering tidak normatif, kosa katanya banyak dipengaruhi bahasa daerah dan unsur leksikal dialek. Selain mengandung unsur leksikal daerah, kalimat tersebut juga mengandung bentuk alegro yaitu pada kata tanya yang merupakan ujaran yang dipendekkan dari kata bertanya, dan pada kata saja yang merupakan ujaran yang dipendekkan dari kata saja.

Dalam konteks pemateri menjawab pertanyaan dan memberikan penjelasan yang lebih konkrit.

Data 2 pada menit 5:56

Cak Nun : Jadi banyak sekali ayat-ayat Al-Quran mengenai ekologi, banyak sekali. Nah, untuk itu kita harus anu, harus, anda harus punya kontak nanti, gitu, karena banyak sekali. Itu jawaban saya ${ }^{1}$ seperti itu, saya tidak perlu detail disini ${ }^{2}$. Tapi, banyak sekali dan everything is all about mizan. Kalau di Al-Quran itu namanya Mizan, kan sekarang anak taunya kan mizan itu penerbit

Peserta : hahahhahaha (tertawa)

Dalam data 2 termasuk variasi bahasa santai karena mengandung bahasa tidak normatif, kalimat elips, dan terdapat penggunaan bahasa asing (bahasa Inggris). Dalam kalimat "Nah, untuk itu kita harus anu, harus, anda harus punya kontak nanti, gitu, karena banyak sekali”, tergolong bahasa tidak normatif karena menggunakan kata "anu" yang mengandung makna ambigu, pengulangan kata harus yang membuat susunan kalimat menjadi rancu, dan penggunaan kata gitu lebih baik tidak digunakan agar menjadi kalimat yang lebih efisien. Data 2 berbentuk kalimat elips 
karena hanya mengandung unsur subjek (pada keterangan nomor 1) dan keterangan (pada keterangan nomor 2), tetapi tidak mengandung unsur predikat. Selain itu juga terdapat penggunaan bahasa asing yaitu bahasa Inggris pada kalimat everything is all about dan penggunaan bahasa Arab pada kata mizan.

Dalam konteks menjawab pertanyaan dan memberikan penjelasan yang lebih detail Data 4 menit 8:39

Cak Nun : zaman dulu, mas Priyo ini mesti tau dikampleng bapak e, mesti. Atau disamblek garisan tanjalin, wes mesti wes. Generasi beliau, saya, mesti tau disamblek. Aku iki dibuwak nang kebon, tau aku. Teko jendela dibuwak nang kebon. Nek saiki polsek teko iku karo anggota komnas HAM teko.

Data 4 termasuk dalam variasi bahasa santai karena mengandung unsur bahasa daerah yaitu bahasa Jawa Timur. Adapun beberapa kata dalam bahasa daerah adalah dikampleng, disamblek, wes, mesti, dibuwak, teko, saiki, karo, dan kebon. Bahkan, salah satu kalimat dalam data ini menggunakan bahasa daerah sepenuhnya "Aku iki dibuwak nang kebon, tau aku teko jendela dibuwak nang kebon", yang mana kalimat ini memiliki makna aku dibuang di kebun, aku pernah dari jendela dibuang ke kebunPenggunaan campur kode bahasa daerah dapat menjadi sebuah sarana untuk menjalin keakraban dengan mitra tutur. Hal ini sejalan dengan pendapat Suwito salah satu faktor penyebab terjadinya campur kode dalam sebuah komunikasi adalah adanya usaha untuk menunjukkan bagaimana hubungan antara mitra tutur dan penutur atau sebagai usaha untuk menjalin keakraban dengan mitra tutur(Rulyandi dkk., 2014:30).

Dalam konteks menjawab pertanyaan dan memberikan penjelasan yang lebih detail Data 5 menit

Cak Nun: Nomor tiga, akuntansi. Perkenalkan anakmu, biasakan anakmu menghitung segala sesuatu, bukan ngitung dalam arti util, tapi me manage ngerti itungane. Nek aku ngene, ibukku atine yaaapa, nek aku ngene guru yaapa, nek aku ngene mene terus aku yaapa. Jadi, punya hitung-hitungan terhadap kehidupan, syukur punya hitungan bisnis hitungan management tapi dengan akhlak yang bagus dan disiplin yang bagus dia tidak mungkin menjadi bisnis oriented atau kapitalis

Data ini termasuk dalam variasi bahasa santai karena mengandung unsur bahasa daerah, bentuk alegro,dan bahasa asing. Dalam kalimat ini "Nek aku ngene, ibukku atine yaaapa, nek aku ngene guru yaapa, nek aku ngene mene terus aku yaapa" secara keseluruhan menggunakan bahasa Jawa Timur. Penggunaan bentuk alegro dapat dilihat dalam kalimat "Perkenalkan anakmu, biasakan anakmu menghitung segala sesuatu, bukan ngitung dalam arti util, tapi me manage ngerti itungane" yaitu pada kata util yang merupakan ujaran yang diperpendek dari kata ngutil atau mencuri. Selain itu, dalam kalimat tersebut juga menggunakan bahasa asing yaitu bahasa Inggris pada manage yang artinya mengelola atau mengatur. Pada kalimat "Jadi, punya hitung-hitungan terhadap kehidupan, syukur punya hitungan bisnis hitungan management tapi dengan akhlak yang bagus dan disiplin yang bagus dia tidak mungkin menjadi bisnis oriented atau kapitalis" terdapat penggunaan bahasa asing yaitu bahasa Inggris pada kata management dan oriented.

Berdasarkan hasil analisis data di atas, terdapat beberapa perbedaan dengan penelitian terdahulu yang memiliki kajian sama. Penelitian yang berjudul Variasi Bahasa Pada Tayangan Kick Andy Dalam Episode "Ngelmu Sampai Mati" dilakukan oleh Fitri Puji Rahmawati dan Sumarlam (2016). Dalam penelitian ini lebih mengkaji variasi bahasa secara keseluruhan yaitu mulai dari variasi bahasa dari segi keformalan, penutur, penggunaan, dan sarana. Variasi bahasa dari sego keformalan ditemukan penggunaan bahasa akrab yang diidentifikasi melalui penggunaan unsur dialek daerah. Penelitian yang berjudul Variasi Keformalan Dalam Wacana Kelas Mahasiswa Angkatan 2016 Kelas A 
Program Studi Pendidikan Bahasa Indonesia Universitas Tadulako dilakukan oleh Sri Sudaryati (2019). Dalam penelitian ini mengkaji tentang variasi bahasa dari segi keformalan antara lain: ragam bahasa resmi, usaha, santai, dan akrab. Dalam menganalisis data yang menjadi suatu indikator adalah dari segi penggunaan bahasa baku dan melihat situasi pada saat terjadinya tuturan. Pada ragam bahasa santai yang ditemukan terjadi pada situasi tuturan yang tidak formal. Perbedaan hasil penelitian terlihat perbedaan yang jelas melalui variasi bahasa santai yang ditemukan mengandung kalimat elips, berbentuk alegro dalam bahasa daerah maupun bahasa Indonesia, dan terdapat penggunaan bahasa asing yaitu bahasa Inggris dan bahasa Arab. Adapun bentuk alegro dalam bahasa daerah yang terdapat dalam tuturan disebabkan oleh latar belakang penutur yang tinggal di daerah tertentu. Begitu pula dengan adanya campur kode dengan bahasa asing seperti bahasa Arab terjadi karena latar belakang penutur yang dikenal sebagai sebagai budayawan dan tokoh agama.

\section{Macam-Macam Bentuk Tuturan Ilokusioner}

Pada kegiatan diskusi publik bersama Cak Nun diperoleh beberapa macam tuturan ilokusioner yaitu tuturan asertif, direktif, komisif, ekspresif, dan deklaratif sebagai berikut.

\section{Tuturan asertif}

Tuturan asertif merupakan tuturan yang mengikat penuturnya akan kebenaran atas apa yang diujarkannya (Ruvianto dkk., 2017:2). Adapun yang termasuk dalam jenis tindak tutur ini adalah tuturan menyatakan, memberitahukan, menuntut, membanggakan, melaporkan, mengeluh, mengusulkan, mengklaim (Rahma, 2018).

Konteks: kegiatan tanya jawab, peserta diperbolehkan bertanya kepada pemateri Data 1 menit ke 00:59

Peserta: Bagaimana kita.. supaya para dosen mempunyai keluasan hati dan cara mengarahkan yang benar karna sedikit-dikit kalo kita mengarahkan sesuai dengan peraturan, saya rasa seperti yang diungkapkan tadi bahwa peraturan itu dibawah dari akhlak, tapi cara mengingatkan akhlak yang benar itu seperti apa, supava kita kita juga enggak disalahkan karna melanggar HAM, ini kan gak masalah karena ini Hak saya Hak saya, seperti itu.

Bentuk kalimat yang ada pada data 2 memenuhi ciri-ciri tuturan asertif langsung yaitu dengan penggunaan kata "kita". Tuturan asertif langsung termasuk dalam tuturan yang berfungsi mengeluh karena posisi sebagai dosen yang disalahkan karena mengingatkan muridnya seperti dalam pemilihan kalimat "supaya kita kita juga enggak disalahkan karna melanggar HAM". Berdasarkan kedua data tersebut terdapat penggunaan kalimat yang bersifat mengeluh yaitu supaya kita enggak disalahkan dan kalimat sangat dibatasi dengan berdaulat, yang mana kalimat tersebut menunjukkan sebuah perasaan yang sedang dialami.

Konteks pemateri menjawab pertanyaan peserta dan memberikan penjelasan yang lebih konkrit.

Data 2 menit 5:15

Cak Nun: Jadi kalau saya ngomong, Wassamaa arafa ahaa wawadhoalmiiizaaan. Itu sudah cukup untuk hukum ekologi. Allah meletakkan bumi, meninggikan langit dan Allah menyiptakan keseimbangan. Lha, keseimbangan itu sampai detail toh dek, misalnya ekosistem di sawah itu keseimbangan, air harus bagaimana hubungannya sama akar pohon, sama hubungannya, aturannya tentang IMB, boleh membangun apa tidak, kan gitu kan dek. Sungai harus bagaimana, semua itu soal keseimbangan.

Kalimat dalam data ini termasuk dalam tuturan asertif karena kalimat ini berfungsi memberitahukan dengan menggunakan verba asertif. Penutur memberitahukan mengenai sebuah ayat $\mathrm{Al}$ Quran yang menjelaskan perkara ekologi. Hal tersebut dapat dilihat melalui pemilihan verba asertif yaitu kata ngomong, kemudian 
dilanjutkan dengan sebuah ayat Al-Quran dan diakhiri dengan penegasan diakhir. Tuturan asertif ini termasuk dalam tuturan asertif langsung karena pemilihan kata saya yang menjadikan kalimat tersebut bersifat aktif karena subjeknya berkenaan secara langsung. Termasuk dalam tuturan asertif yang bersifat langsung karena pemilihan kata saya yang menunjukkan keterlibatan subjek secara langsung.

Konteks pemateri menjawab pertanyaan peserta dan memberikan penjelasan yang lebih konkrit.

Data 3 menit 12:25

Cak Nun : Jadi, belum pernah ada drama yang penontonnya sampai 35 ribu ke atas hampir 40 ribu di stadion Madian,Makasar, Jogja dimana-mana. Yang sekarang harus anda bangun itu budi pekerti.

Dalam kalimat pada data ini termasuk dalam tuturan asertif karena menggunakan verba asertif yang memiliki ciri membanggakan. Ciri membanggakan dapat dilihat melalui pemilihan kalimat belum pernah ada drama yang penontonnya sampai 35 ribu ke atas hampir 40 ribu memperlihatkan bahwa hal tersebut sebagai pencapaian yang besar dan belum pernah ada yang bisa melakukannya. Tuturan asertif ini termasuk dalam tuturan asertif tak langsung karena tidak menggunakan subjek yang berkenaan secara langsung.

\section{Tuturan Direktif}

Tuturan direktif disebut juga dengan tuturan impositif, yakni tuturan ilokusi yang dimaksudkan penuturnya agar mitra tutur melakukan tindakan yang disebutkan di dalam tuturan itu (Ruvianto, 2017:2). Adapun yang termasuk kedalam kategori tindak tutur ini antara lain meminta, memerintah, memohon, menyarankan, menasehati. Tindak ilokusi direktif memiliki kinerja verbal memerintah yang paling eksplisit jika dibandingkan dengan tindak ilokusi lain. Holmes menyatakan keeksplisitan tindak ilokusi direktif bisa dilihat dari hubungan langsung antara daya ilokusi dengan struktur kalimatnya (Mudiono, 2014:99).
Konteks pemateri menjawab pertanyaan peserta dan memberikan penjelasan yang lebih konkrit.

Data 1 menit 12:25

Cak Nun : iyo toh, jadi pelajarilah ilmu rububiyah. Endi mau sing takon, pelajarilah ilmu rububiyah. Dolek o engko di google lak ono ah, tapi aja langsung percaya pada apa yang anda baca di google, harus ada rekonfirmasi dan istikharah kepada Allah SWT.

Kalimat dalam data ini termasuk dalam tuturan direktif yang berfungsi menyarankan dan memerintah. Dalam kalimat "jadi pelajarilah ilmu rububiyah" pemilihan kata pelajarilah yang diikuti partikel lah menjadi sebuah saran untuk melakukan suatu perbuatan tertentu. Kemudian dalam kalimat "Dolek o engko di google lak ono ah" merupakan tuturan direktif yang berfungsi memerintah karena menggunakan verba dolek o atau carilah menjadi sebuah kata yang bertujuan memerintah seseorang.

Konteks pemateri menjawab pertanyaan peserta dan memberikan penjelasan yang lebih konkrit.

Data 2 menit 16:21

Cak Nun : setiap zaman punya jalan keluarnya sendiri, yang penting anda melakukan yang harus anda lakukan, jangan cemaskan mengenai dunia, dunia milik Allah dan Allah mengkhilafahi inna lanaddzikro wa inna lahafidun, Allah menjaga semua yang cinta padanya tenang saja yah.

Kalimat dalam data ini termasuk tuturan direktif yang berfungsi menasehati. Dalam kalimat "jangan cemaskan mengenai dunia, dunia milik Allah" menggunakan kata jangan cemaskan menjadi penekanan dalam nasehat yang disampaikan penutur dan kata cemaskan merupakan verba performatif yang berasal dari verba dasar cemas dan partikel kan.

Konteks pemateri menjawab pertanyaan peserta dan memberikan penjelasan yang lebih konkrit.

Data 3 menit 25:29 
Cak Nun: Jadi saya.. mari kita,... saya cuman minta sama anda gini. Kita Alfathiha kemudian kita yakini Allah melakukan 3 hal, satu menciptakan anda, mengatur seluruh faktor-faktor kehidupan anda, dan nomer tiga memperindah tatanan yang sudah ditata Allah. Itu dan itu rumuskan oleh 3 asma 3 nama yaitu al-kholik, al-bari', al-musowiru. Jadi, nanti saya mohon anda mengucapkan al-kholik, al-bari', al-musowiru, mudah-mudahan malaikat nyacet.

Kalimat dalam data ini termasuk tuturan direktif yang berfungsi meminta dan memohon. Dalam kalimat "saya cuman minta sama anda gini. Kita Alfathiha kemudian kita yakini Allah melakukan 3 hal, satu menciptakan anda, mengatur seluruh faktor-faktor kehidupan anda, dan nomer tiga memperindah tatanan yang sudah ditata Allah.", termasuk tuturan direktif yang berfungsi meminta secara eksplisit dapat dilihat melalui pemilihan kata saya cuman minta. Kemudian pada kalimat "Jadi, nanti saya mohon anda mengucapkan al-kholik, albari', al-musowiru, mudah-mudahan malaikat nyacet" kalimat ini termasuk tuturan direktif yang berfungsi memohon yang secara eksplisit dapat dilihat dengan pemilihan kata saya mohon.

\section{Tuturan Komisif}

Tindak tutur komisif adalah tindak tutur yang melibatkan penuturnya pada tindakan yang akan datang seperti berjanji, bersumpah, menawarkan, memanjatkan (doa).

Konteks pemateri menjawab pertanyaan peserta dan memberikan penjelasan yang lebih konkrit.

Data 1 menit 22:17

Cak Nun : terus Tuhan takon, terus karepmu yaapa Nun? Loh, sampean lak ndawuhi kanjeng nabi Muhammad al a'mallu bin niyat walikulliri'im man nawa, setiap orang itu tergantung niatnya dan akan mendapat sesuai dengan yang diniatinya
Kalimat pada data ini termasuk tuturan komisif yang berfungsi promises. Hal tersebut dalam dilihat melalui kalimat "setiap orang itu tergantung niatnya dan akan mendapat sesuai dengan yang diniatinya" makna dalam kalimat ini adalah berjanji karena kalimat tersebut merupakan kalimat yang berasal dari Nabi Muhammad yang pasti dipercaya oleh orang Islam.

Konteks pemateri menjawab pertanyaan peserta dan memberikan penjelasan yang lebih konkrit.

Data 1 menit 19:35

Cak Nun: Nomor tiga, akuntansi, perkenalkan anakmu biasakan anakmu menghitung segala sesuatu, bukan ngitu dalam arti util, tapi me manage ngerti itungane. Nek aku ngene, ibukku atine yaaapa, nek aku ngene guru yaapa, nek aku ngene mene terus aku yaapa. Jadi, punya hitung-hitungan terhadap kehidupan, syukur punya hitungan bisnis hitungan management tapi dengan akhlak yang bagus dan disiplin yang bagus dia tidak mungkin menjadi bisnis oriented atau kapitalis.

Kalimat dalam data ini termasuk tuturan komisif berfungsi offers karena dalam kalimat "Jadi, punya hitung-hitungan terhadap kehidupan, syukur punya hitungan bisnis hitungan management tapi dengan akhlak yang bagus dan disiplin yang bagus dia tidak mungkin menjadi bisnis oriented atau kapitalis. ", menjadi sebuah tuturan tawaran karena mengandung makna jika dia memiliki management atau perhitungan terhadap segala sesuatu kemudian disertai dengan akhlak yang bagus maka dia tidak akan menjadi bisnis yang oriented.

\section{Tuturan Ekspresif}

Ekspresif (Expressives): Tindak tutur ekspresif merupakan tindak tutur yang berfungsi menyatakan atau menunjukkan sikap psikologis penutur terhadap suatu keadaan, seperti berterima kasih, meminta maaf, memuji, meyalahkan, 
mengucapkan selamat, memaafkan dan berbelasungkawa.

Konteks menjawab pertanyaan dan memberikan penjelasan yang lebih konkrit

Data 1 menit 21:25

Cak Nun : dalam arti untuk perjuangan, gitu ya temen-temen sekalian yah. Mudah-mudahan ini membuat anda mendapatkan listrik yang baru dalam hidup anda dan saya minta maaf untuk semua kekurangankekurangan saya, terus jawaban sing gak pas ya ancene gak onok sing pas temen, yah.

Kalimat dalam data ini merupakan tuturan ekspresif karena menggunakan kata yang menunjukkan perasaan atau emosi seseorang. Kalimat "saya minta maaf untuk semua kekurangan-kekurangan saya," penggunaan kata minta maaf sebagai sebuah ekspresi penutur meminta maaf atas kesalahan yang telah dilakukan.

Konteks menjawab pertanyaan dan memberikan penjelasan yang lebih konkrit

Data 2 menit 4:33

Cak Nun : Kalo anda adalah Sultan Hamengkubawana berarti anda adalah sekjen alam semesta, yang ngurusi planet-planet dan galaksigalaksi berarti anda adalah malaikat Jibril. Nah, kalo anda panglimanya manusia penglunanya manusia berarti anda bernama Hamengkubuwana. Nek bawana berarti malaikat Jibril terus Cak Nun kok gak bantah, lho aku ya seneng no, berarti sultan Jogja iku malaikat Jibril.

Kalimat dalam data ini merupakan tuturan ekspresif karena mengandung kata interjeksi. Dalam kalimat "Nek bawana berarti malaikat Jibril terus Cak Nun kok gak bantah, lho aku ya seneng no." Penggunaan kata interjeksi kata lho menunjukkan ekspresi yang menandakan penutur yakin dengan apa yang dikatakan. Selain itu, penggunaan kata seneng dapat menjadi ciri tuturan ekspresif karena mengungkapkan perasaan yang senang
Konteks menjawab pertanyaan dan memberikan penjelasan yang lebih konkrit

Data 3 menit 4:33

Cak Nun : Masio kon nggeledak 6 wulan gak mati-mati ya iso. Aku iku tau marani kanca di Klaten loro berbulan-bulan nggletak, sampe adekno njaga kepegelan. Waduh, maturnuwun Cak, aku tak muleh diluk cak, aku njaga mbendino rina-ringa wengi aku pegel Cak.

Kalimat pada data ini merupakan tuturan ekspresif karena mengandung kata interjeksi. Kalimat "Waduh, maturnuwun Cak, aku tak muleh diluk cak" penggunaan kata interjeksi waduh menggambarkan ekspresi seseorang yang sedang kagum. Selain itu, terdapat penggunaan matursuwun merupakan kata yang menggambarkan ekspresi rasa syukur terhadap suatu pemberian.

Konteks menjawab pertanyaan dan memberikan penjelasan yang lebih konkrit

Data 4 menit 4:33

Cak Nun : iso gak Allah gawe ngunu? Ngunu nek aku urip gak usah angel-angel, itu temenan dek. Alhamdulillah loh rek aku gak tau loro, 63 tahun aku saiki, nek mati aja dihubungno karo sehat.

Kalimat dalam data ini merupakan tuturan ekspresif karena mengandung kata interjektif. Kalimat "Alhamdulillah loh rek aku gak tau loro, 63 tahun aku saiki, nek mati aja dihubungno karo sehat" penggunaan kata interjeksi Alhamdulillah tersebut menggambar rasa bersyukur kepada Tuhan.

\section{Tuturan Direktif}

Deklaratif (Declaration): Keberhasilan pelaksanaan ilokusi ini akan menimbulkan kesesuaian antara isi proporsi dengan realitas, misalnya menyerahkan diri (berpasrah), memecat, membebaskan, membaptis, menamai, mengucilkan, mengangkat, menunjuk, menentukan, menjatuhkan hukuman. 
Konteks menjawab pertanyaan dan memberikan penjelasan yang lebih konkrit

Data 1 menit 18:47

Cak Nun: Keras kok gak boleh, makanya yang nomor dua tadi anak harus mengalami kekerasan, kekerasan itu adalah sembahyang titik kudu gelem titik tangi titik iki wes setengah enem titik adus titik, keras.

Kalimat dalam data ini merupakan tuturan deklaratif yang berfungsi memutuskan. Pada kalimat "anak harus mengalami kekerasan" terdapat kata harus yang menjadi indikator dalam memutuskan suatu hal tertentu. Dalam tuturan deklaratif yang berfungsi memutuskan sudah sesuai dengan konteks pembicaraan yang berkaitan dengan ibadah yang bersifat wajib.

Konteks menjawab pertanyaan dan memberikan penjelasan yang lebih konkrit

Data 2 menit 20:29

Cak Nun : Aku mambengi nang nggon e petinju Nur Huda mampir sakdurunge nang kendal payah, Nur Huda lak anakku biyen petinju jenenge si macan tutul, kan saya bapaknya semua petinju-petinju Indonesia.

Kalimat dalam data ini merupakan tuturan deklaratif yang berfungsi menamai. Pada kalimat "Nur Huda lak anakku biyen petinju jenenge si macan tutul, kan saya bapaknya semua petinju-petinju Indonesia" penggunaan kata jenenge si macan tutul menjadi indikator kata yang memberikan suatu nama atau julukan tertentu. Kemudian pada kalimat "kan saya bapaknya semua petinju-petinju Indonesia" menunjukkan suatu usaha memberikan nama atau julukan pada diri sendiri menjadi bapaknya petinju-petinju dengan menggunakan kan saya.

Konteks menjawab pertanyaan dan memberikan penjelasan yang lebih konkrit

Data 3 menit 4:33
Cak Nun : terus yang kerja di kantor di istana di kementrian semua itu kan pegawai negeri yang sudah berpuluh-puluh tahun. Sekarang pelajari di Majapahit kabinetnya bagaimana itu menentukan rubrikasi cara berpikir Majapahit, misale di Majapahit ada menteri urusan sudra dan orang asing, misalnya yah, takono pak Agus Suyoto.

Kalimat dalam data ini termasuk dalam tuturan deklaratif berfungsi menentukan. Pada kalimat "Sekarang pelajari di Majapahit kabinetnya bagaimana itu menentukan rubrikasi cara berpikir Majapahit" secara eksplisit melalui penggunaan kata menentukan menjadi salah satu dalam tuturan deklaratif berfungsi menentukan. Dalam kalimat tersebut memiliki makna ketika mempelajari kabinet dalam Majapahit dapat menentukan rubrikasi cara berpikir pemerintahannya.

Berdasarkan hasil analisis data di atas, terdapat beberapa perbedaan dengan penelitian terdahulu yang memiliki kajian sama. Penelitian yang berjudul Tindak Tutur Ilokusi Pendakwah Dalam Program Damai Indonesiaku di TV ONE dilakukan oleh Roli Stambo dan Syahrul Ramadhan (2019). Dalam penelitian mengkaji tentang tindak tutur ilokusi dan diperoleh beberapa bentuk tindak tutur ilokusi seperti direktif, komisif, ekspresif, asertif, dan deklarasi yang mana dalam penentuannya dilakukan melalui verba yang digunakan dalam suatu tuturannya. Penelitian yang berjudul Analisis Tindak Tutur Ilokusi Dalam Dialog Film Animasi Meraih Mimpi dilakukan oleh Anis Nurulita Rahma (2018). Dalam penelitian ini mengkaji tentang tindak tutur ilokusi beserta fungsi tindak tutur ilokusi. berdasarkan hasil analisis data diperoleh macam-macam tindak tutur ilokusi berdasarkan verba yang digunakan sedangkan fungsi tindak tutur ilokusi diperoleh melalui makna eksplisit maupun implisit yang terdapat dalam tuturan. Terdapat perbedaan yang diperoleh dari hasil penelitian yaitu tindak tutur ilokusi diperoleh menggunakan indikator partikel lah pada tuturan direktif dan pada tuturan 
ekspresif terdapat penggunaan kata interjektif dalam tuturan penutur.

\section{SIMPULAN}

Bahasa daerah sebagai bahasa Ibu sangat mendominasi dalam komunikasi yang terjadi dalam kegiatan diskusi publik Kedaulatan dan Kebudayaan bersama Cak Nun. Cak Nun berperan sebagai pemateri dengan latar belakang seorang budayawan dari Jombang Jawa Timur. Selama proses kegiatan diskusi Cak Nun menggunakan bahasa yang terindikasi sebagai variasi bahasa santai. Terdapat beberapa karakteristik atau ciri-ciri variasi bahasa santai dalam kegiatan diskusi yaitu mengandung campuran unsur bahasa Jawa baik secara keseluruhan atau sebagian, mengandung alegro, mengandung campur kode bahasa asing yaitu bahasa Inggris dan bahasa Arab, mengandung bahasa tidak normatif karena pemilihan kata yang bersifat ambigu, dan kalimat elips yang tidak mengandung unsur predikat. Selain variasi bahasa santai terdapat pula macam-macam bentuk tuturan ilokusioner antara lain tuturan asertif; tuturan direktif; tuturan komisif; tuturan ekspresif; dan tuturan deklaratif. Tuturan asertif dalam diskusi ini meliputi tuturan yang bertujuan menyarankan, memberitahukan dan membanggakan. Terdapat tuturan direktif yang bertujuan memerintah, menasehati, meminta, dan memohon.Tuturan komisif yang bertujuan promises (berjanji) dan offer (menawarkan). Tuturan ekspresif yang menunjukkan perasaan terimakasih, meminta maaf, senang, dan kagum. Tuturan Deklaratif yang bertujuan untuk memutuskan, menamai, dan menentukan. Cak Nun sebagai pemateri menggunakan variasi bahasa santai dapat menjadi suatu upaya menjalin keakraban dengan mitra tutur sehingga pesan dari kegiatan diskusi dapat tersampaikan dengan baik. Selain itu, dalam kegiatan diskusi terdapat beberapa macam bentuk tuturan ilokusioner yang ditemukan sesuai konteks.

\section{DAFTAR PUSTAKA}

Andini, H. M. (2017). Jenis-Jenis Tindak Tutur Dan Mkana Pragmatik Bahasa Guru Pada Pembelajaran Bahasa
Indonesia Di SMA Negeri 1 Karangreja Kabupaten Purbalingga Tahun Ajaran 016/2017. Universitas Sanata Dharma, Skripsi.

A'yuni, N. B. Q., \& Parji, P. (2017). Tindak tutur ilokusi novel Surga Yang Tidak Dirindukan karya Asma Nadia (kajian pragmatik). Linguista: Jurnal Ilmiah Bahasa, Sastra, dan Pembelajarannya, 1(1), 6-11.

Chaer, A., \& Agustina, L. (2014). Sosiolinguistik: Suatu pengantar. Rineka Cipta.

Handika, K. D., Sudarma, I. K., \& Murda, I. N. (2019). Analisis Penggunaan Ragam Bahasa Indonesia Siswa dalam Komunikasi Verbal. Jurnal Pedagogi dan Pembelajaran, 2(3),

Hayati, R. (2021). VARIAS.

Ibrahim. (2009). Kesemestaan Sosiolinguistik. Universitas Malang.

Ibrahim, A. S. (1993). Kajian Tindak Tutur. Usaha Nasional.

Kemendikbud Turut Peringati Hari Bahasa Ibu Internasional. (2020, Februari 24). Kementerian Pendidikan, Kebudayaan, Riset, Dan Teknologi. https://www.kemdikbud.go.id/main/bl og/2020/02/kemendikbud-turutperingati-hari-bahasa-ibuinternasional

Kontribusi Kosakata Bahasa Daerah dalam Bahasa Indonesia | Badan Pengembangan dan Pembinaan Bahasa, Kementerian Pendidikan dan Kebudayaan. (t.t.). Diambil 28 Mei 2021, dari http://badanbahasa.kemdikbud.go.id/l amanbahasa/content/kontribusikosakata-bahasa-daerah-dalambahasa-indonesia

Koyimah, H. (2018). Tindak Tutur Ilokusi Dalam Acara Indonesia Lawyers Club Tv One Episode "Jokowi - Prabowo Berbalas Pantun" Dan Implikasinya Pada Pembelajaran Bahasa Indonesia SMA. Universitas Muhammadiyah Surakarta, Skripsi.

Kridalaksana, Harimurti.2007. Kelas Kata dalam Bahasa Indonesia. Jakarta:PT Gramedia.

Malabar, S. (2015). Sosiolinguistik. Ideas Publishing. 
Mudiono, A. (2014). Tindak Ilokusi Bahasa Indonesia Dalam Interaksi Keluarga. Lingua: Jurnal Bahasa, Sastra, dan Pengajarannya, 11(1).

Nurulita, P., Jaya, W. S., \& Rachmasisca, F. M. (2019). Tindak Tutur Dalam Kegiatan Diskusi Siswa Pada Pembelajaran Berbicara Kelas X Smk Pgri 2 Bandar Lampung Tahun Pelajaran 2018/2019. Warahan: Jurnal Ilmiah Mahasiswa Pendidikan Bahasa dan Sastra Indonesia, 1(1), 115.

Prasasti, B. W. D., \& Mujianto, G. (2020). Pemakaian Akrolek Pada Tuturan Asertif Dalam Gelar Wicara Hitam Putih. Jurnalistrendi: Jurnal Linguistik, Sastra, Dan Pendidikan, 5(2), 147-164.

Rahma, A. N. (2018). Analisis Tindak Tutur Ilokusi dalam Dialog Film Animasi Meraih Mimpi. Jurnal. Surabaya: Skriptorium, 2(2).

Ramadhanti, D. (2018). Wujud Perilaku Berkarakter Dalam Tuturan Siswa Berlatar Budaya Minangkabau: Tinjauan Sosiolinguistik Interaksional. Jurnal Gramatika, 4(2).

Rulyandi, Rohmadi, M., \& Sulistyo, E. T. (2014). Alih Kode Dan Campur Kode Dalam Pembelajaran Bahasa Indonesia Di SMA. Jurnal Paedagogia, 17(1).

Ruvianto, A. W., Rustono, R., \& Sulistyaningrum, S. (2017). Tuturan Ilokusi pada Acara Mata Najwa di Metro TV. Jurnal Sastra Indonesia, 6(3), 1-6.

Setianingsih, E. (2013). Register Nelayan Di Pantai Depok Parangtritis Kretek Bantul. Universitas Negeri Yogyakarta, Skripsi.

Stambo, R., \& Ramadhan, S. (2019). Tindak Tutur Ilokusi Pendakwah Dalam Program Damai Indonesiaku Di Tv One. Basindo: Jurnal Kajian Bahasa, Sastra Indonesia, Dan Pembelajarannya, 3(2), 250-260.

Sudaryati, S. (2019). Variasi Keformalan Dalam Wacana Kelas Mahasiswa Angkatan 2016 Kelas A Program Studi Pendidikan Bahasa Indonesia Universitas Tadulako. 4(1), 13.
Suryatin, E. (2018). Tindak Tutur Direktif Bahasa Indonesia Pada Poster Kesehatan Di Puskesmas Kota Banjarbaru. Jurnal Undas, 14(2).

Titasari, E. R. (2017). Tindak Tutur Ilokusi Deklaratif Para Guru Dalam Interaksi Belajar Mengajar Pada Siswa Kelas X SMK YOS Sudarso Rembang. Universitas Sanata

Utama,dkk. (2021). Tuturan Imperatif Bermakna Positif Pada Spanduk Di Kota Pekanbaru. Jurnal Geram. 9(1).

Yayuk, R. (2014). Tindak Tutur Asertif Dalam Basa-Basi Banjar. Jurnal Multilingual, Vol XIII(No 1). 